\title{
The Zur of Xanthomonas campestris Is Involved in Hypersensitive Response and Positively Regulates the Expression of the hrp Cluster Via hrpX But Not hrpG
}

\author{
Dong-Liang Huang, Dong-Jie Tang, Qing Liao, Xiao-Qian Li, Yong-Qiang He, Jia-Xun Feng, Bo-Le Jiang, \\ Guang-Tao Lu, and Ji-Liang Tang
}

Guangxi Key Laboratory of Subtropical Bioresources Conservation and Utilization, The Key Laboratory of Ministry of Education for Microbial and Plant Genetic Engineering, and College of Life Science and Technology, Guangxi University, 100 Daxue Road, Nanning, Guangxi 530004, China

Submitted 22 July 2008. Accepted 13 November 2008.

\begin{abstract}
In bacteria, Zur is a key regulator for zinc homeostasis. Our previous work has shown that, in the phytopathogen Xanthomonas campestris pv. campestris, in addition to regulating zinc homeostasis, Zur is essential for full virulence. Here, we demonstrate that the $X$. campestris pv. campestris Zur is involved in hypersensitive response (HR) and positively regulates the transcription of $h r p A$ to $h r p F$ operons and $h r p X$ but not $h r p G$. Constitutively expressing $h r p X$ but not $h r p G$ in the zur mutant could bypass the requirement of Zur for the expression of hrpA to hrpF operons and the induction of wild-type $H R$, indicating that Zur controls the expression of $h r p$ cluster via $h r p X$. Promoter-gusA reporter and semiquantitative reverse-transcription polymerase chain reaction analyses revealed that HrpG controls the expression of $h r p X$ and $\mathrm{HrpX}$ regulates the expression of all the six hrp operons ( $h r p A$ to hrpF) in $X$. campestris pv. campestris.
\end{abstract}

Hypersensitive response (HR) is a disease-resistant phenomenon with a type of rapid, localized, and programmed cell death, which is induced by a pathogen at the infection sites of resistant hosts and nonhost plants (Alfano and Collmer 2004; Jones and Dangl 2006). A number of genes associated with HR and pathogenicity ( $h r p$ ) in phytopathogenic bacteria have been characterized and most of them cluster on one chromosome (Alfano and Collmer 1997; Büttner and Bonas 2006; Lindgren 1997). Most of the hrp cluster genes encode the type III secretion system (T3SS) that is highly conserved among gramnegative pathogenic bacteria and translocates effector proteins into host cells (Cornelis and Van Gijsegem 2000; He 1998; Hueck 1998). In Xanthomonas spp., the hrp cluster consists of six operons ( $h r p A$ to $h r p F$ ) which harbor more than 20 different genes (Arlat et al. 1991; Bonas et al. 1991; Büttner et al. 2003; Gürlebeck et al. 2006). The expression of these hrp

\section{D.-L. Huang and D.-J. Tang contributed equally to this work.}

Current address for D.-L. Huang: Guangxi Sugarcane Research Institute, Nanning, Guangxi 530007, China.

Current address for Q. Liao: Soil and Fertilizer Research Institute, Guangxi Academy of Agricultural Sciences, Nanning, Guangxi 530007, China.

Corresponding author: J.-L. Tang; Telephone: 86-771-3239566; Fax: 86771-3239413; E-mail: jltang@gxu.edu.cn

*The $\boldsymbol{e}$-Xtra logo stands for "electronic extra" and indicates that a supplemental table is available online. genes is controlled positively by two key regulators, $h r p G$ and $h r p X$, whose loci are far away from the hrp cluster on the chromosome (Büttner and Bonas 2006; Weber et al. 2007). $\mathrm{HrpG}$ is predicted to be an OmpR family's response regulator of two-component signal transduction systems, and $\mathrm{HrpX}$ is an AraC-type transcriptional activator. In Xanthomonas campestris pv. vesicatoria, the causal agent of bacterial spot disease in pepper and tomato, HrpG and HrpX form a regulatory cascade, in which HrpG regulates the expression of the $h r p A$ operon and $h r p X$, and HrpX then activates the expression of other hrp operons ( $h r p B$ to $h r p F$ ) (Wengelnik and Bonas 1996; Wengelnik et al. 1996b). Although the hrp clusters among Xanthomonas spp. are highly conserved (Büttner et al. 2003; Gürlebeck et al. 2006), the regulatory cascade controlling expression of the hrp operons in different species or pathovars other than $X$. campestris pv. vesicatoria has not been experimentally verified.

In bacteria, the zinc uptake regulator Zur usually functions as a repressor of $\mathrm{Zn}^{2+}$ uptake systems to maintain zinc homeostasis (Hantke 2001, 2005). Recently, we have demonstrated that, in addition to playing a role in zinc homeostasis, the Zur of $X$. campestris pv. campestris is essential for full virulence (Tang et al. 2005) and also acts as an activator of a $\mathrm{Zn}^{2+}$ efflux pump, apart from acting as a repressor of $\mathrm{Zn}^{2+}$ uptake systems (Huang et al. 2008). X. campestris pv. campestris is the causal agent of black rot disease of cruciferous crops worldwide (Hayward 1993). The pathogen attacks not only economically important cruciferous vegetables and the major oil crop rape but also the model plant Arabidopsis thaliana. In the last more than two decades, it has been used as a model bacterium for studying plant-pathogen interactions, and a large number of hrp genes and genes implicated in virulence have been characterized (Arlat et al. 1991; Daniels et al. 1984a; Dow et al. 2003; He et al. 2007b; Qian et al. 2005; Tang et al. 1991). In this article, we described that the Zur of X. campestris pv. campestris is a novel key regulator for the expression of hrp genes, which positively regulates the expression of the hrp cluster through $h r p X$. Furthermore, we demonstrated that, in $X$. campestris pv. campestris, HrpX activates not only the expression of $h r p B$ to $h r p F$ operons but also the expression of $h r p A$.

\section{RESULTS}

The Zur of $X$. campestris pv. campestris is involved in HR.

Our previous work showed that, $24 \mathrm{~h}$ after inoculation, the zur mutant 1430nk (Table 1) induced a wild-type HR in a nonhost local pepper cultivar inoculated by infiltrating bacterial 
suspension with a cell concentration of $1 \times 10^{8} \mathrm{CFU} / \mathrm{ml}$ (Tang et al. 2005). To valuate the role of the $X$. campestris pv. campestris Zur in HR precisely, in this study, we investigated the HR of the zur-mutant strain 1430nk on the pepper cv. ECW-10R (Capsicum annuum cv. ECW-10R), one of the pepper cultivars typically used to test the HR of $X$. campestris $\mathrm{pv}$. campestris (Castañeda et al. 2005; Newman et al. 2001). The results showed that the zur mutant 1430nk and the wild-type strain 8004 elicited almost identical HR symptoms 16 h after inoculation (Fig. 1). However, $8 \mathrm{~h}$ after inoculation, the zur mutant 1430 nk was unable to trigger a visual HR on the inoculated leaves, whereas the wild type induced normal HR symptoms (Fig. 1). The complemented strain C1430nk (Table 1) (i.e., the mutant 1430nk harbors an entire X. campestris pv. campestris zur cloned in the broad-host-range vector pLAFR6) (Huynh et al. 1989) stimulated a wild-type HR $8 \mathrm{~h}$ after inoculation (Fig. 1), indicating that the HR-induction capacity of the zur mutant could be completely restored by zur in trans. These results demonstrate that zur is involved in HR induction of $X$. campestris pv. campestris.

\section{Zur regulates positively the expression} of $h r p$ operons ( $h r p A$ to $h r p F)$ and $h r p X$ but not hrpG.

To determine whether zur has any regulatory relations with hrp genes, the plasmid-driven promoter $\beta$-glucuronidase (gus)A transcriptional fusion reporter plasmids pGUShrpA, pGUShrp $B$, pGUShrpC, pGUShrpD, pGUShrpE, pGUShrpF, pGUShrpG, and pGUShrpX (Table 1), in which a DNA fragment containing the promoter region of each of the six hrp operons ( $h r p A$ to $h r p F$ ) and the two key $h r p$ regulators ( $h r p G$ and $h r p X)$ of $X$. campestris pv. campestris fused to the promoterless gusA gene with its ribosome binding site (RBS) was cloned into the vector pLAFR6, were introduced from the $E s$ cherichia coli JM109 (Yanisch-Perron et al. 1985) into the zur mutant 1430nk and the wild-type strain 8004 by the triparental conjugation as described by Turner and associates (1985) using
pRK2073 (Leong et al. 1982) as the helper plasmid. Transconjugants were screened on the rich medium NYG (Daniels et al. 1984a) supplemented with appropriate antibiotics. The obtained reporter strains were named 1430nk(pGUShrpA), 1430nk (pGUShrpB), 1430nk(pGUShrpC), and so on. In Xanthomonas spp., the expression of hrp genes, including the regulators $h r p G$ and $h r p X$, has been shown to be induced in nutrient-deficient media but repressed in nutrient-rich media (Tang et al. 2006; Wengelnik et al. 1996a). Therefore, we measured the GUS activities of the obtained reporter strains in the minimal medium MMX (Daniels et al. 1984b). The results showed that the GUS activity of each of these hrp-gusA reporter plasmids, except pGUShrpG, in the zur mutation background was significantly ( $t$ test, $P=0.01$ ) lower than that in the wild-type background (Table 2), indicating that the transcription of all six $h r p$ operons ( $h r p A$ to $h r p F$ ) and the $h r p$ regulator $h r p X$ is positively regulated by Zur in $X$. campestris pv. campestris. The GUS activities of the $h r p G$-promoter-gusA transcriptional fusion reporter plasmid in the zur-mutation background and the wild-type background (i.e., strains 1430nk(pGUShrpG) and 8004(pGUShrpG)) are almost identical (Table 2), suggesting that Zur is not required for the transcription of $h r p \mathrm{G}$.

\section{HrpX activates the expression of $h r p A$ to $h r p F$ operons in $X$. campestris pv. campestris.}

As described above, the organization of the $h r p A$ to $h r p F$ operons in $X$. campestris pvs. vesicatoria and campestris is similar (Büttner et al. 2003) and it has been demonstrated that, in $X$. campestris pv. vesicatoria, $\mathrm{HrpG}$ activates the expression of the $h r p A$ operon and $h r p X$, and HrpX then activates the expression of $h r p B$ to $h r p F$ operons but not $h r p A$ (Wengelnik and Bonas 1996; Wengelnik et al. 1996b). To determine the regulatory relationship among the hrp genes in $X$. campestris pv. campestris, the reporter plasmids pGUShrpA, pGUShrpB, pGUShrpC, pGUShrpD, pGUShrpE, pGUShrpF, pGUShrpG, and pGUShrpX (Table 1) were introduced from the $E$. coli

Table 1. Bacterial strains and plasmids used in this work

\begin{tabular}{|c|c|c|}
\hline Strains or plasmids & Relevant characteristics $^{\mathrm{z}}$ & Reference or source \\
\hline \multicolumn{3}{|l|}{ Escherichia coli } \\
\hline JM109 & $\begin{array}{l}\text { RecA } 1, \text { endA } 1, \text { gyrA96, thi, supE44, relA } 1 \Delta(\text { lac-proAB }) / \mathrm{F}^{\prime}\left[\text { traD } 36, \text { lacI }{ }^{\mathrm{q}} \text {, }\right. \\
\text { lacZAM15] }\end{array}$ & Yanisch-Perron et al. 1985 \\
\hline \multicolumn{3}{|c|}{ Xanthomonas campestris pv. campestris } \\
\hline 8004 & Wild type, Rif $^{\mathrm{r}}$ & Daniels et al. 1984a \\
\hline $1430 \mathrm{nk}$ & As 8004 , but $z u r:: p K 18 m o b, \operatorname{Rif}^{\mathrm{T}}, \mathrm{Kan}^{\mathrm{r}}$ & Tang et al. 2005 \\
\hline C1430nk & Complemented strain of $1430 \mathrm{nk}, \mathrm{Rif}^{\mathrm{r}}, \mathrm{Kan}^{\mathrm{r}}, \mathrm{Tc}^{\mathrm{r}}$ & Tang et al. 2005 \\
\hline $8004 \mathrm{G}$ & $8004 \Delta h r p G, \operatorname{Rif}^{\mathrm{r}}, \mathrm{Kan}^{\mathrm{r}}$ & Wei et al. 2007 \\
\hline $8004 \mathrm{X}$ & $8004 \Delta h r p X, \mathrm{Rif}^{\mathrm{r}}, \mathrm{Kan}^{\mathrm{r}}$ & Wei et al. 2007 \\
\hline hrcV mutant & As 8004 , but the coding region of $h r c V(X C 3013)$ has been deleted, Rif ${ }^{\mathrm{r}}$ & Laboratory collection \\
\hline $1430 \mathrm{nk}(\mathrm{pR} 3 \mathrm{G})$ & 1430nk harboring $\mathrm{pR} 3 \mathrm{G}, \mathrm{Rif}^{\mathrm{r}}, \mathrm{Kan}^{\mathrm{r}}, \mathrm{Tc}^{\mathrm{r}}$ & This work \\
\hline 8004(pR3G) & 8004 harboring pR3G, $\operatorname{Rif}^{\mathrm{r}}, \mathrm{Kan}^{\mathrm{r}}, \mathrm{Tc}^{\mathrm{r}}$ & This work \\
\hline $1430 \mathrm{nk}(\mathrm{pR} 3 \mathrm{X})$ & 1430nk harboring pR3X, $\mathrm{Rif}^{\mathrm{T}}, \mathrm{Kan}^{\mathrm{r}}, \mathrm{Tc}^{\mathrm{r}}$ & This work \\
\hline $8004(\mathrm{pR} 3 \mathrm{X})$ & 8004 harboring pR3X, Rif ${ }^{\mathrm{r}}, \mathrm{Kan}^{\mathrm{r}}, \mathrm{Tc}^{\mathrm{r}}$ & This work \\
\hline $8004 \mathrm{G}(\mathrm{pR} 3 \mathrm{X})$ & 8004G harboring pR3X, Rif ${ }^{\mathrm{r}}, \mathrm{Kan}^{\mathrm{r}}, \mathrm{Tc}^{\mathrm{r}}$ & This work \\
\hline \multicolumn{3}{|l|}{ Plasmids } \\
\hline pLAFR6 & Broad host range cloning vector, $\mathrm{Tc}^{\mathrm{r}}$ & Huynh et al. 1989 \\
\hline pLAFR3 & Broad host range cloning vector, $\mathrm{Tc}^{\mathrm{r}}$ & Huynh et al. 1989 \\
\hline pRK2073 & Helper plasmid, $\mathrm{Tra}^{+}, \mathrm{Mob}^{+}, \mathrm{ColE} 1, \mathrm{Spc}^{\mathrm{r}}$ & Leong et al. 1982 \\
\hline pXC1430 & pLAFR6 containing an 833-bp fragment including zur gene, $\mathrm{Tc}^{\mathrm{r}}$ & Tang et al. 2005 \\
\hline $\mathrm{pR} 3 \mathrm{X}$ & pLAFR 3 containing a 1,523-bp fragment including promoterless $h r p X$ gene, $\mathrm{Tc}^{\mathrm{r}}$ & This work \\
\hline $\mathrm{pR} 3 \mathrm{G}$ & pLAFR3 containing an 899-bp fragment including promoterless $h r p G$ gene, $\mathrm{Tc}^{\mathrm{r}}$ & This work \\
\hline pGUShrpA & pLAFR6 containing an $h r p A$ operon promoter-gus $A$ fusion fragment, $\mathrm{Tc}^{\mathrm{r}}$ & Laboratory collection \\
\hline pGUShrpB & pLAFR6 containing an $h r p B$ operon promoter-gus $A$ fusion fragment, $\mathrm{Tc}^{\mathrm{r}}$ & Laboratory collection \\
\hline pGUShrpC & pLAFR6 containing an $h r p C$ operon promoter-gusA fusion fragment, $\mathrm{Tc}^{\mathrm{r}}$ & Laboratory collection \\
\hline pGUShrpD & pLAFR6 containing an $h r p D$ operon promoter-gusA fusion fragment, $\mathrm{Tc}^{\mathrm{r}}$ & Laboratory collection \\
\hline pGUShrpE & pLAFR6 containing an $h r p E$ operon promoter-gus $A$ fusion fragment, $\mathrm{Tc}^{\mathrm{r}}$ & Laboratory collection \\
\hline pGUShrpF & pLAFR6 containing an $h r p F$ operon promoter-gusA fusion fragment, $\mathrm{Tc}^{\mathrm{r}}$ & Laboratory collection \\
\hline pGUShrpG & pLAFR6 containing an $h r p G$ promoter-gusA fusion fragment, $\mathrm{Tc}^{\mathrm{r}}$ & Laboratory collection \\
\hline pGUShrpX & pLAFR6 containing an $h r p X$ promoter-gusA fusion fragment, $\mathrm{Tc}^{\mathrm{r}}$ & Laboratory collection \\
\hline
\end{tabular}

${ }^{\mathrm{z}} \mathrm{Rif}^{\mathrm{r}}, \mathrm{Kan}^{\mathrm{r}}, \mathrm{Spc}^{\mathrm{r}}$, and $\mathrm{Tc}^{\mathrm{r}}=$ rifampicin, kanamycin, spectinomycin, and tetracycline resistant, respectively. 
JM109 into the $h r p G$-mutant strain $8004 \mathrm{G}$, hrpX-mutant strain $8004 \mathrm{X}$, and the wild-type strain 8004 by triparental conjugation. The GUS activities of the resulting reporter strains were measured after being grown in the minimal medium MMX. The results showed that the GUS activity of each of these hrpgusA reporter plasmids in the $h r p G$ or $h r p X$ mutation background was significantly ( $t$ test, $P=0.01$ ) lower than that in the wild-type background (Table 2), indicating that, in $X$. campestris pv. campestris, HrpX regulates the expression of all the six $h r p$ operons ( $h r p A$ to $h r p F$ ). The reporter plasmids pGUS $h r p G$ and pGUShrpX were also introduced into the $h r p X$ mutant and hrpG mutant, respectively. The GUS activity produced by the reporter plasmid pGUShrpX in the $h r p G$ mutant was significantly lower than that in the wild type (Table 2), denoting that the expression of $h r p X$ is positively regulated by HrpG in $X$. campestris pv. campestris.

In $X$. campestris pv. vesicatoria, hrpA is activated by $\mathrm{HrpG}$ but not HrpX (Wengelnik and Bonas 1996). However, the data shown in Table 2 demonstrate that both HrpX and HrpG are required for the activation of hrpA in $X$. campestris pv. campestris.
Because the expression of $h r p X$ is activated by $\mathrm{HrpG}$, it is possible that HrpG regulates $h r p A$ via $h r p X$. To clarify this possibility, the low-copy-number vector pLAFR3 with an E. coli lac promoter flanking the multiple cloning sites (Huynh et al. 1989), which expresses constitutively in $X$. campestris (Wengelnik et al. 1996a), was used to construct the recombinant plasmid pR3X (Table 1), in which the promoterless $h r p X$ of $X$. campestris pv. campestris with its authentic RBS was cloned into pLAFR3 in an orientation that allowed the $h r p X$ to be driven by the lac promoter (details below). The plasmid pR3X constitutively expressing $h r p X$ was then introduced into the $h r p G$ mutant $8004 \mathrm{G}$ and the RNA level of $h r p A$ in the resulting strain $8004 \mathrm{G}(\mathrm{pR} 3 \mathrm{X})$ was assessed by semiquantitative reverse-transcription polymerase chain reaction (RT-PCR). The results showed that the hrpA RNA level in $8004 \mathrm{G}(\mathrm{pR} 3 \mathrm{X})$ was similar to that in the wild-type strain (Fig. 2A), suggesting that HrpG activates the expression of hrpA through hrpX in $X$. campestris pv. campestris. Taken together, the above results indicate that, in contrast to the situation in $X$. campestris pv. vesicatoria, HrpG does not control hrpA directly in $X$. campestris pv. campestris.
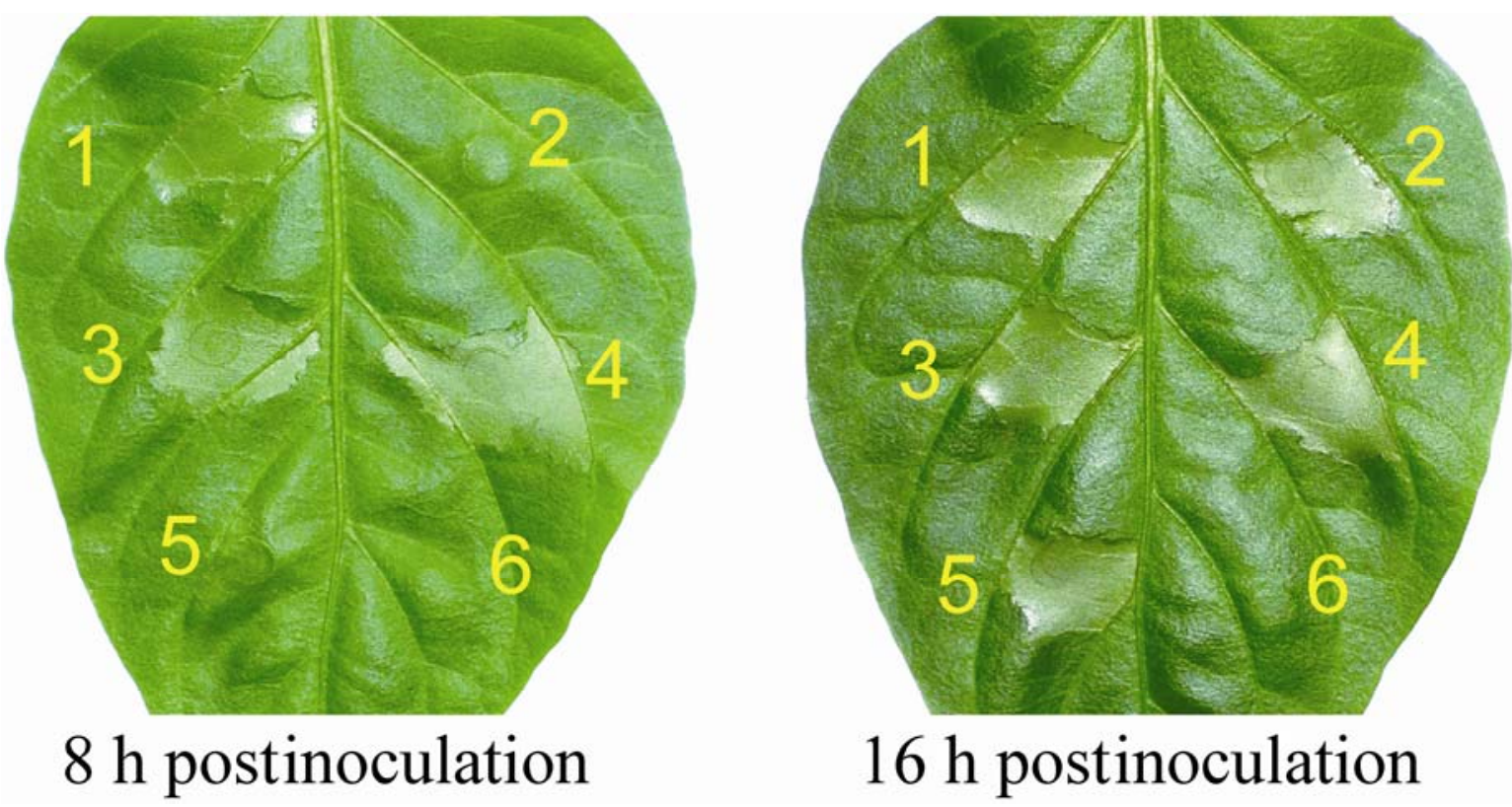

Fig. 1. Hypersensitive response (HR) symptoms induced in pepper leaves (Capsicum annuum cv. ECW-10R) by Xanthomonas campestris pv. campestris strains The plants were inoculated by infiltrating approximately $5 \mu \mathrm{l}$ of bacterial suspension $\left(1 \times 10^{8} \mathrm{CFU} / \mathrm{ml}\right)$ in $10 \mathrm{mM}$ sodium phosphate buffer $(5.8 \mathrm{mM}$ $\mathrm{Na}_{2} \mathrm{HPO}_{4}$ and $4.2 \mathrm{mM} \mathrm{NaH}_{2} \mathrm{PO}_{4}, \mathrm{PH} 7.0$ ) into the pepper leaves using a blunt-end plastic syringe. The inoculated plants were maintained in a greenhouse with a 12-h day and night cycle with illumination by fluorescent lamps and a constant temperature of $28^{\circ} \mathrm{C}$. HR symptoms were observed and photographed at 8 and $16 \mathrm{~h}$ post inoculation, respectively. At least three plants were inoculated in each experiment and each experiment was repeated twice. The results presented are from a representative experiment and similar results were obtained in all other independent experiments; 1 , wild-type strain 8004; 2, zur-mutant 1430nk; 3, complemented strain C1430nk; 4, strain 1430nk(pR3X); 5, strain 1430nk(pR3G); and 6, type III secretion system-deficient strain (hrcV mutant; negative control).

Table 2. $\beta$-Glucuronidase (GUS) activities of the $h r p$ promoter-gusA reporters in different genetic backgrounds grown in the minimal medium MMX

\begin{tabular}{lcccc}
\hline & \multicolumn{4}{c}{ GUS activities $(\mathbf{U})$ in $^{\mathbf{z}}$} \\
\cline { 2 - 5 } Reporter plasmid & $\mathbf{8 0 0 4}$ (wild type) & 1430nk (zur mutant) & $\mathbf{8 0 0 4 G}$ (hrpG mutant) & $\mathbf{8 0 0 4 X}(\boldsymbol{h r p} \boldsymbol{X}$ mutant) \\
\hline pGUShrpA & $1.11 \pm 0.27 \mathrm{~A}$ & $0.36 \pm 0.11 \mathrm{~B}$ & $0.14 \pm 0.03 \mathrm{C}$ & $0.12 \pm 0.04 \mathrm{C}$ \\
pGUShrpB & $1.99 \pm 0.24 \mathrm{~A}$ & $0.32 \pm 0.06 \mathrm{~B}$ & $0.10 \pm 0.02 \mathrm{C}$ & $0.08 \pm 0.01 \mathrm{C}$ \\
pGUShrpC & $1.91 \pm 0.17 \mathrm{~A}$ & $0.37 \pm 0.02 \mathrm{~B}$ & $0.11 \pm 0.02 \mathrm{C}$ & $0.13 \pm 0.03 \mathrm{C}$ \\
pGUShrpD & $1.69 \pm 0.17 \mathrm{~A}$ & $0.25 \pm 0.04 \mathrm{~B}$ & $0.08 \pm 0.01 \mathrm{C}$ & $0.12 \pm 0.03 \mathrm{C}$ \\
pGUShrpE & $1.56 \pm 0.36 \mathrm{~A}$ & $0.42 \pm 0.09 \mathrm{~B}$ & $0.18 \pm 0.02 \mathrm{C}$ & $0.17 \pm 0.02 \mathrm{C}$ \\
pGUShrpF & $1.33 \pm 0.15 \mathrm{~A}$ & $0.46 \pm 0.04 \mathrm{~B}$ & $0.10 \pm 0.01 \mathrm{C}$ & $0.10 \pm 0.01 \mathrm{C}$ \\
pGUShrpG & $0.99 \pm 0.03 \mathrm{~A}$ & $0.91 \pm 0.06 \mathrm{~A}$ & $\mathrm{ND}$ & $1.01 \pm 0.04 \mathrm{~A}$ \\
pGUShrpX & $0.92 \pm 0.04 \mathrm{~A}$ & $0.26 \pm 0.06 \mathrm{~B}$ & $0.09 \pm 0.01 \mathrm{C}$ & $\mathrm{ND}$ \\
\hline
\end{tabular}

${ }^{\mathrm{z}}$ GUS activities were determined after growth of Xanthomonas campestris pv. campestris strains in the minimal medium MMX for $48 \mathrm{~h}$. Data are the mean \pm standard deviation of triplicate measurements. The different letters in each horizontal data column indicate significant differences at $P=0.01$. The experiment was repeated twice and similar results were obtained. ND $=$ not done. 
To get some clues about the differentiation of the hrpA regulation between $X$. campestris pv. campestris and $X$. campestris pv. vesicatoria, we compared their intergenic region (IGR) DNA sequences between $h r p B 8$ and $h r c C$ ( $h r p A$ operon). The result showed that i) the lengths of the two IGR are different, 176 and 81 bp in $X$. campestris pv. campestris and $X$. campestris pv. vesicatoria, respectively; and ii) their first 26 nucleotide sequences upstream of $h r c C$ start codons are highly conserved ( $88 \%$ identity) but the remainders show low sequence similarity (Fig. 3). These sequence variations may relate to the hrpA regulation diversity between $X$. campestris pv. campestris and $X$. campestris pv. vesicatoria (discussed below).

\section{Zur activates the expression of $h r p A$}

to $h r p F$ operons through HrpX.

It has been demonstrated that, in $X$. campestris pv. vesicatoria, HrpX regulates the transcription of hrp genes by directly binding to the plant-inducible promoter (PIP) box present in the promoters of $h r p$ operons (Koebnik et al. 2006). It is possible that, in $X$. campestris pv. campestris, Zur does not regulate directly the expression of the six hrp operons but, instead, via HrpX that then controls directly the expression of the hrp genes with the PIP box. If so, constitutively expressing $h r p X$ but not $h r p G$ would bypass the requirement of zur for the expression of $h r p$ genes. To verify this hypothesis, a recombinant plasmid named pR3G (Table 1), which constitutively expresses hrpG, was also constructed by cloning the promoterless $h r p G$ of $X$. campestris pv. campestris into pLAFR3 similarly to the construction of the recombinant plasmid $\mathrm{pR} 3 \mathrm{X}$ above. The plasmids $\mathrm{pR} 3 \mathrm{X}$ and $\mathrm{pR} 3 \mathrm{G}$ were introduced into the zur mutant 1430nk and the wild-type strain 8004 by triparental conjugation, respectively. The obtained transconjugant strains were named 1430nk (pR3X), 8004(pR3X), 1430nk(pR3G), and 8004(pR3G) (Table 1). The virulence and HR of these strains were determined in the

A

hrcC (hrpA operon)

$16 \mathrm{~S}$ rDNA

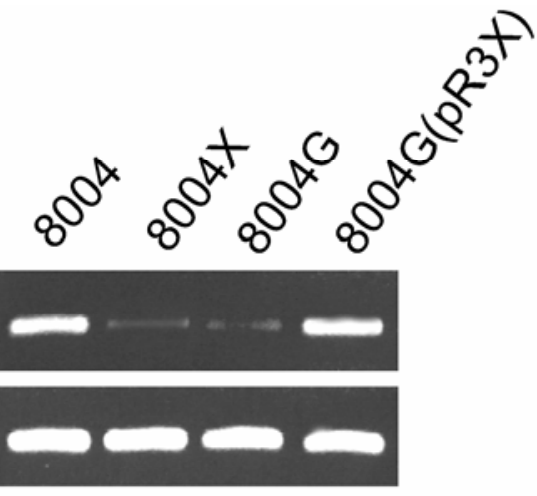

B

hrcC ( $h r p A$ operon)

hrpB8 ( $h r p B$ operon)

hrcU ( $h r p C$ operon)

$h r c R$ ( $h r p D$ operon)

hrpE ( $h r p E$ operon)

hrpF (hrpF operon)

hrpX

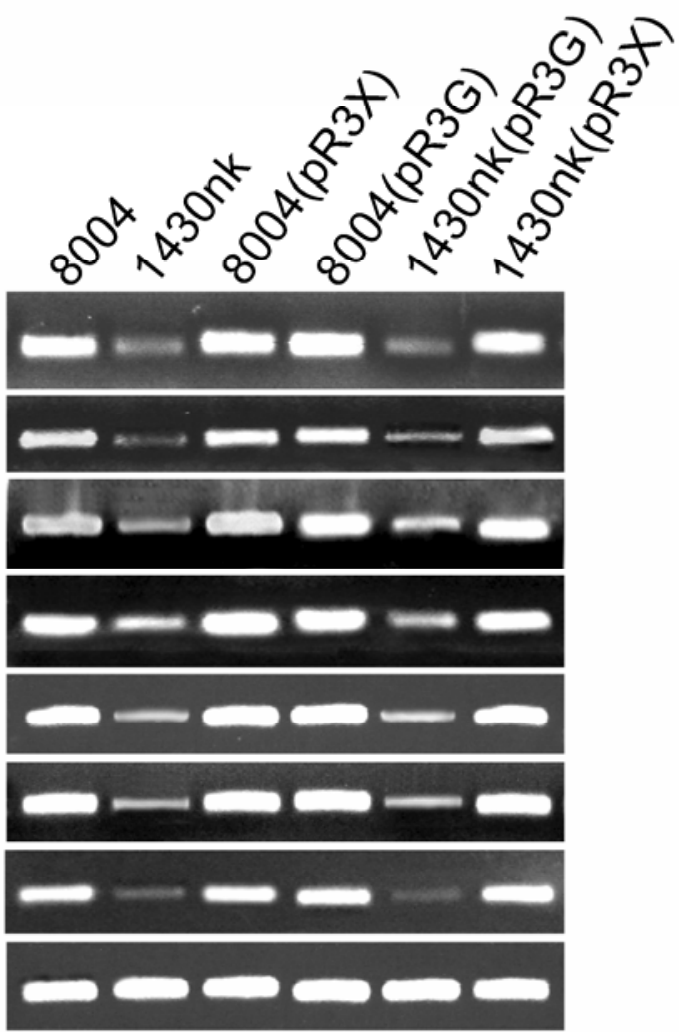

16S rDNA

Fig. 2. Detection of the mRNA level of hrp genes in Xanthomonas campestris pv. campestris strains by semiquantitative reverse-transcription polymerase chain reaction (PCR). RNA was isolated from cultures of the X. campestris pv. campestris strains grown to an optical density at $600 \mathrm{~nm}$ of 1.0 in the MMX medium (Daniels et al. 1984b). The same amount of RNA from the testing strains in the same comparable group was used to convert to cDNA using a TaKaRa RNA PCR Kit (AMV; ver. 3.0; TaKaRa). PCR amplifications with Taq polymerase were performed by using the obtained cDNAs as templates and the related primer sects. The obtained PCR products were analyzed in $1.2 \%$ agarose gels. The $16 \mathrm{~S}$ rRNA gene of $X$. campestris pv. campestris was used as the internal control to verify the absence of significant variation at cDNA level in the samples. The experiment was repeated twice and similar results were obtained. 
host plant Chinese radish (Raphanus sativus L. var. radiculus Pers.) and the nonhost plant pepper ECW-10R. As shown in Figure 1, the strain 1430nk(pR3X) induced a wild-type HR, while the strain $1430 \mathrm{nk}(\mathrm{pR} 3 \mathrm{G})$ induced a delayed and weakened HR similar to that caused by the zur mutant $1430 \mathrm{nk}$, indicating that constitutively expressing $h r p X$ but not $h r p G$ in the zur mutant could completely restore the HR-eliciting capability of the mutant. This demonstrates that $X$. campestris pv. campestris Zur affects the expression of the hrp cluster of genes via HrpX. The mean lesion length caused by $1430 \mathrm{nk}(\mathrm{pR} 3 \mathrm{X})$ was far shorter than that produced by the wild type, although it was significantly ( $t$ test, $P=0.01$ ) longer than that produced by the zur mutant (Table 3 ), suggesting that constitutively expressing $h r p X$ in the zur mutant could only partially restore the virulence of the zur mutant. Constitutive expression of hrpG in the zur mutant strain and the wild-type strain did not alter significantly the virulence of the strains (Table 3).

To investigate whether the HR restoration of the zur mutant 1430nk by constitutively expressing $h r p X$ accompanies the restoration of the mRNA level of the relative $h r p$ genes, we assayed the mRNA level of $h r c C$ (XC3003) ( $h r p A$ operon), $h r p B 8$ (XC3004) ( $h r p B$ operon), $h r c U$ (XC3012) ( $h r p C$ operon), $h r c R$ (XC3016) ( $h r p D$ operon), hrpE (XC3021) ( $r r p E$ operon), $h r p F$ (XC3025) (hrpF operon), and hrpX (XC3076) in the strains 1430nk(pR3X) and 1430nk(pR3G) by semiquantitative RT-PCR. As shown in Figure 2B, i) the mRNA levels of all the tested hrp genes in strains 8004, 8004(pR3X), and 8004(pR3G) were similar, indicating that constitutive expression of $h r p G$ or $h r p X$ in the wild-type background did not increase the expression of downstream genes significantly; and ii) the mRNA levels of all the tested $h r p$ genes in the strain 1430nk(pR3X) were similar to those in the strain 8004(pR3X) but significantly higher than those in the strain 1430nk(pR3G), suggesting that zur does not regulate the transcription of $h r p G$. In addition, the recombinant plasmid pR3G could fully restore the virulence and HR of the $h r p G$ mutant to wild type (data not shown), indicating that the $\mathrm{pR} 3 \mathrm{G}$ construct expresses a functional HrpG protein. These observations further demonstrate that Zur positively regulates the transcription of $h r p X$ but not $h r p G$ and the former then controls the expression of the hrpA to hrpF operons in X. campestris pv. campestris.

\section{The effects of Zur on HR induction, extracellular polysaccharide production, and zinc homeostasis are probably through different regulatory pathways.}

Our previous work has shown that inactivation of zur also resulted in a reduction of extracellular polysaccharide (EPS) of $X$. campestris pv. campestris (Tang et al. 2005). It has been well established that EPS is an important virulence factor of $X$. campestris pv. campestris (Chan and Goodwin 1999). To verify whether or not constitutively expressing $h r p X$ in the zur mutant 1430nk can restore the EPS production of the mutant, we measured the EPS production of 1430nk(pR3X). The result showed that the EPS yield of 1430nk(pR3X) was almost the same as that of the zur mutant 1430nk (Table 3), indicating that constitutively expressing $h r p X$ cannot restore the EPS production of the zur mutant. This result fits in with the above observation that constitutively expressing $h r p X$ could only partially restore the virulence of the zur mutant. However, in addition to EPS, whether there are other virulence factors affected by zur in $X$. campestris pv. campestris remains to be investigated. Nevertheless, these results demonstrate that the regulation of EPS production by zur is not mediated by hrpX in X. campestris pv. campestris. In addition, we compared the $\mathrm{Zn}^{2+}$ tolerance of strain 1430nk(pR3X) and the zur mutant 1430nk, and found that constitutively expressing $h r p X$ did not alter the $\mathrm{Zn}^{2+}$ tolerance of the zur mutant (data not shown). Overall, these results reveal that the HR induction, EPS production, and $\mathrm{Zn}^{2+}$ homeostasis controlled by Zur is achieved through different regulatory cascades in X. campestris pv. campestris.

\section{Zur does not bind to the $h r p X$ promoter in vitro under conditions contented for the binding of Zur to the promoter of genes involved in zinc homeostasis.}

It has been demonstrated that Zur can regulate gene expression directly or indirectly, and the mechanism of the direct regulation is through the binding of Zur to the promoter region of target genes (Huang et al. 2008; Outten and O'Halloran 2001; Patzer and Hantke 2000). To determine whether Zur regulates the expression of $h r p X$ directly in $X$. campestris pv. campestris, we employed an electrophoretic mobility shift assay (EMSA) to study whether Zur binds to the $h r p X$ promoter in vitro. An $\mathrm{His}_{6}$-tagged Zur protein of $X$. campestris pv. campestris was purified as described previously (Huang et al.

Table 3. Effects of constitutive expression of $h r p X$ and $h r p G$ on the virulence and extracellular polysaccharide (EPS) production of Xanthomonas campestris pv. campestris strains ${ }^{\mathrm{Z}}$

\begin{tabular}{lcc}
\hline Strains & Lesion length $(\mathbf{m m})$ & EPS yield (g/liter) \\
\hline 8004 & $12.2 \pm 3.4 \mathrm{~A}$ & $13.7 \pm 0.2 \mathrm{~A}$ \\
$1430 \mathrm{nk}$ & $1.5 \pm 1.1 \mathrm{~B}$ & $4.5 \pm 0.4 \mathrm{~B}$ \\
$1430 \mathrm{nk}(\mathrm{pXC} 1430)$ & $11.6 \pm 2.8 \mathrm{~A}$ & $14.9 \pm 0.4 \mathrm{~A}$ \\
$8004(\mathrm{pR} 3 \mathrm{G})$ & $11.5 \pm 2.9 \mathrm{~A}$ & $12.9 \pm 0.6 \mathrm{~A}$ \\
$1430 \mathrm{nk}(\mathrm{pR} 3 \mathrm{G})$ & $1.2 \pm 0.7 \mathrm{~B}$ & $4.4 \pm 0.3 \mathrm{~B}$ \\
8004(pR3X) & $11.8 \pm 2.4 \mathrm{~A}$ & $13.2 \pm 0.8 \mathrm{~A}$ \\
1430nk(pR3X) & $4.6 \pm 1.2 \mathrm{C}$ & $4.9 \pm 0.6 \mathrm{~B}$ \\
\hline
\end{tabular}

${ }^{\mathrm{z}}$ Virulence and EPS production were assayed by the methods described previously (Tang et al. 2005).Virulence of the X. campestris pv. campestris strains was tested on the host plant Chinese radish (Raphanus sativus L. var. radiculus Pers.) by leaf-clipping. The concentration of bacterial inocula was optical density at $600 \mathrm{~nm}=0.1$. Lesion length was measured 10 days post inoculation. Values are the means \pm standard deviations from three repeats, each with 60 leaves. EPS production of the strains was measured after grown in NYG medium (Daniels et al. 1984a) containing $4 \%$ glucose at $28^{\circ} \mathrm{C}$ with shaking at $200 \mathrm{rpm}$ for 5 days. Data are the means \pm standard deviations of triplicate measurements. The same experiment was repeated three times, and similar results were obtained. Different letters in each data column indicate significant differences at $P=$ 0.01

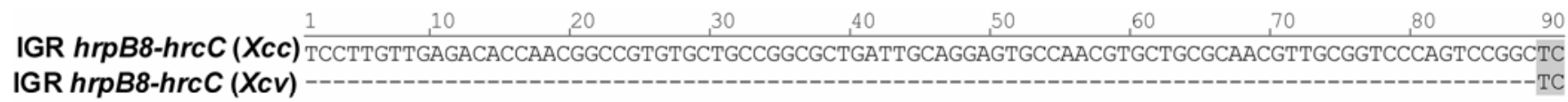

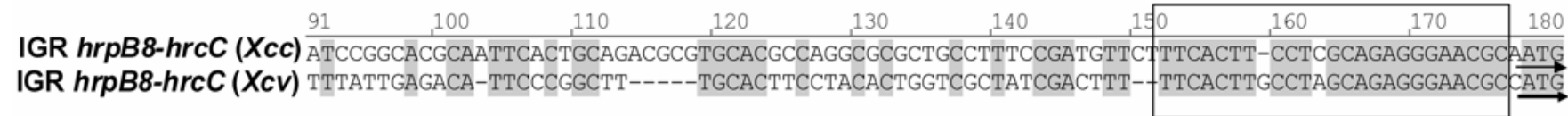

Fig. 3. Alignment of the nucleotide sequence of the intergenic regions (IGR) between hrB8 and hrcC of Xanthomonas campestris pv. campestris and X. campestris pv. vesicatoria. The two sequences were from the sequence databases of National Center for Biotechnology Information (GenBank accession numbers CP000050 for X. campestris pv. campestris 8004 genome and AM039952 for X. campestris pv. vesicatoria 85-10 genome). The boxed area denotes the conserved region and the arrow indicates the start codon and the orientation of $h r c C$ open reading frame. 
2008). A 230-bp DNA fragment containing the $h r p X$ promoter, named $\mathrm{P}_{h r p X}$, was amplified by PCR using the total DNA of the $X$. campestris pv. campestris wild-type strain 8004 as template and the primer set PhrpX-F/PhrpX-R (Supplementary Table S1). The binding ability of the purified $X$. campestris pv. campestris $\mathrm{His}_{6}$-Zur to the amplified $h r p X$ promoter DNA fragment $\mathrm{P}_{h r p X}$ was then tested by EMSA as described previously (Huang et al. 2008). The result showed that the $X$.

\section{[Zur] (nM)}

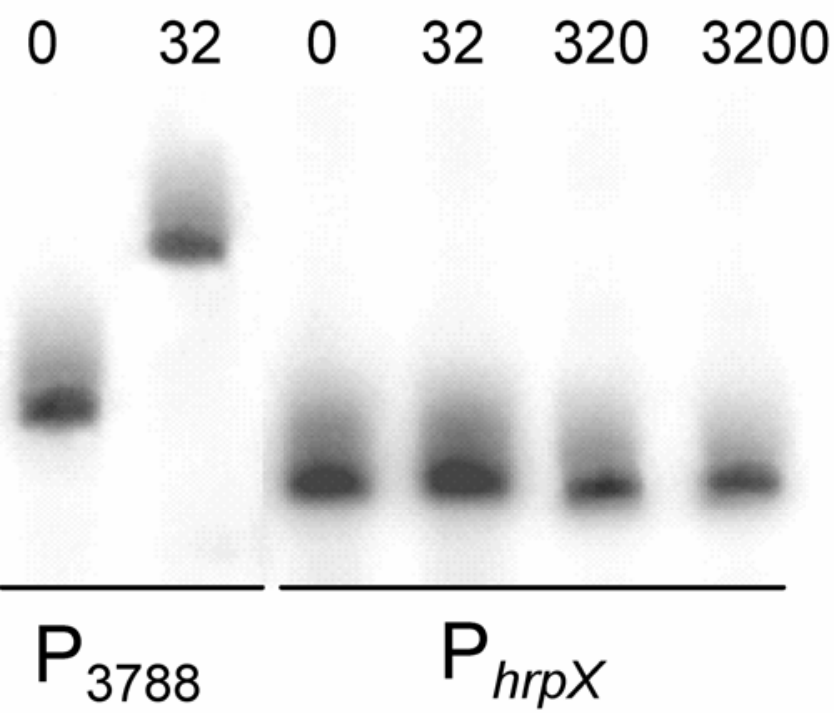

Fig. 4. Determination of Zur-binding to promoter regions by electrophoretic mobility shift assay. His $_{6}$-Zur protein was incubated with 3 pmol of ${ }^{32} \mathrm{P}$-end-labeled DNA fragment containing the promoter region of XC3788 $\left(\mathrm{P}_{3788}\right)$ or $h r p X\left(\mathrm{P}_{h r p X}\right)$ in $20 \mu \mathrm{l}$ of binding buffer $(20 \mathrm{mM}$ Tris-HCl [pH 8], $50 \mathrm{mM} \mathrm{KCl}, 1 \mathrm{mM}$ dithiothreitol, $5 \%$ glycerol, bovine serum albumin at $0.1 \mathrm{mg} / \mathrm{ml}$, and sheared salmon sperm DNA at $5 \mu \mathrm{g} / \mathrm{ml}$ ) at $28^{\circ} \mathrm{C}$ for 15 min, and then analyzed by $4 \%$ polyacrylamide gel electrophoresis. The experiment was repeated twice and similar results were obtained. campestris pv. campestris $\mathrm{His}_{6}$-Zur did not bind to the DNA fragment $\mathrm{P}_{h r p X}$ even at a very high level $(3,200 \mathrm{nM})$ of $\mathrm{His}_{6}$-Zur (Fig. 4), although it bound with a high affinity to $\mathrm{P}_{3788}$ (Fig. 4), a 275-bp DNA fragment containing the promoter of $X C 3788$, a gene that has been demonstrated to be directly regulated by Zur (Huang et al. 2008). This result suggests that Zur may regulate $h r p X$ indirectly in $X$. campestris pv. campestris, or the binding of Zur with the $h r p X$ promoter needs other conditions which are present in vivo.

\section{DISCUSSION}

This study has demonstrated that the $X$. campestris pv. campestris Zur is implicated in HR and positively regulates the transcription of hrp cluster and $h r p X$ but not hrpG. The data presented in this article further demonstrated that Zur controls the transcription of $h r p A$ to $h r p F$ operons via HrpX. Constitutive expression of $h r p G$ could not restore the transcription level of the hrp cluster in the zur mutant to wild type, suggesting that Zur does not act as a regulator for the transcription of hrpG. However, whether Zur acts as a post-transcriptional regulator of $h r p G$ or a cofactor required for HrpG to fully activate $h r p X$ and downstream $h r p$ operons remains to be further investigated.

Recently, it has been shown that, similar to the $X$. campestris pv. campestris Zur, the $X$. oryzae pv. oryzae Zur is also required for $\mathrm{Zn}^{2+}$ homeostasis, virulence, and EPS production (Yang et al. 2007). Interestingly, from a whole-genome microarray hybridization analysis, He and co-workers (2007a) found that the Zur of $X$. campestris pv. campestris XC1 does not regulate the expression of hrp genes. This observation reflects that different $X$. campestris pv. campestris strains may have evolved genetic diversity of the Zur regulatory functions on pathogenicity and other physiological traits. Indeed, it has been shown that, in the strain XC1, Zur is not required for EPS production, although its involvement in HR production is unknown (He et al. 2007a).

The hrp cluster ( $h r p A$ to $h r p F$ operons) and the hrp key regulators $h r p G$ and $h r p X$ are highly conserved among different Xanthomonas spp. and pathovars; therefore, it has long
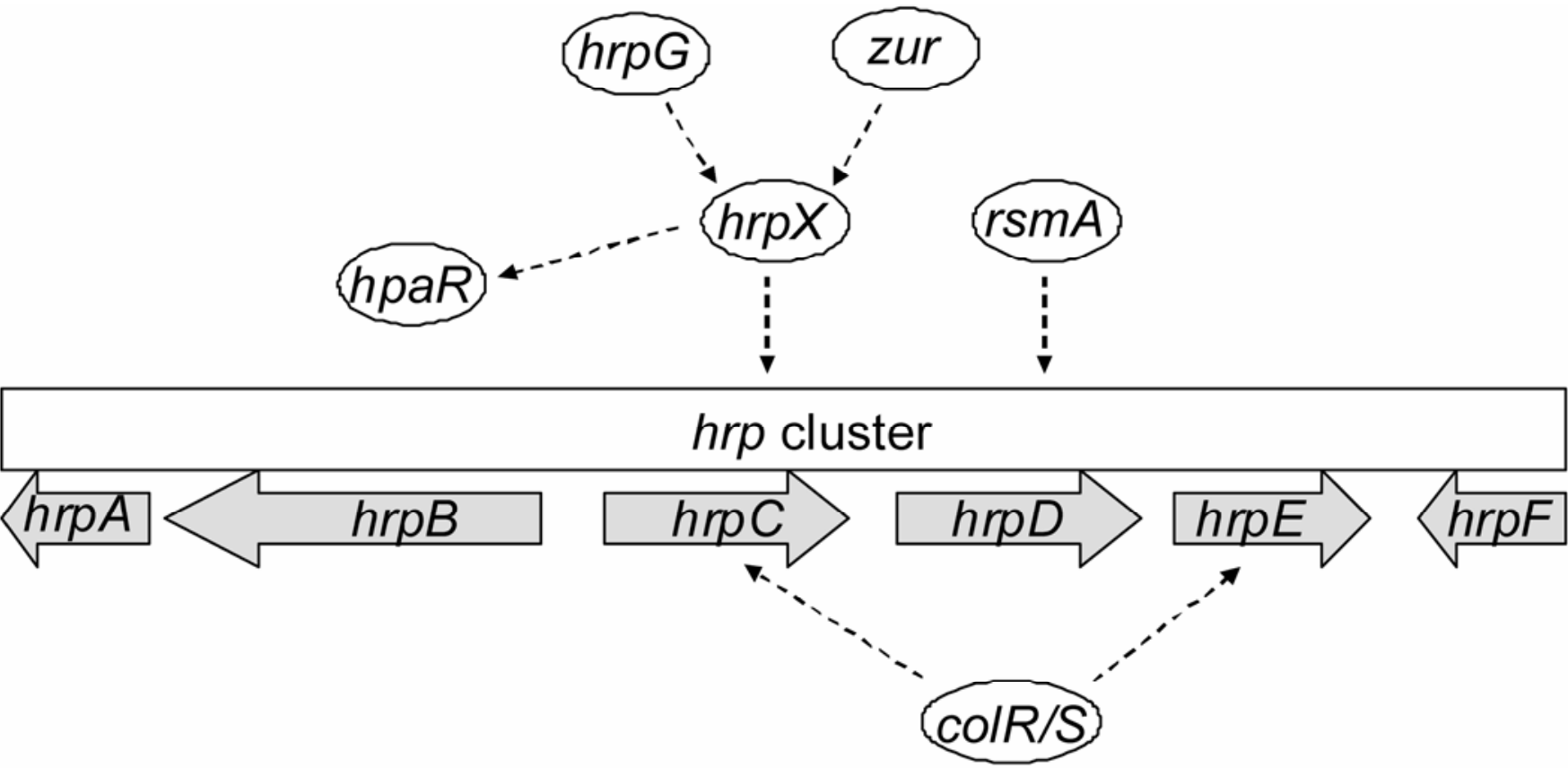

Fig. 5. Working model of hrp gene regulation in Xanthomonas campestris pv. campestris. HrpG and Zur regulate positively the expression of hrpX and HrpX then activates the $h r p$ cluster of genes ( $h r p A$ to $h r p F$ operons) and $h p a R$. $r s m A$ and $c o l R / S$ are not regulated by Zur, HrpG, or HrpX. RsmA positively controls the expression of the $h r p$ cluster ( $h r p A$ to $h r p F$ operons) while ColR/S is required for the expression of $h r p C$ and $h r p E$ operons only. 
been considered that the regulation of the hrp cluster is similar among different Xanthomonas bacteria. In this work, we have validated genetically that, in $X$. campestris pv. campestris, similar to the HrpG of $X$. campestris pv. vesicatoria, HrpG regulates positively the expression of $h r p X$; however, HrpX controls the expression of all of the six hrp operons (i.e., hrpA to $h r p F$ ), differing from the finding in $X$. campestris pv. vesicatoria in which HrpX controls the expression of only five of the six $h r p$ operons (i.e., $h r p B$ to $h r p F$ but not $h r p A$ ) (Wengelnik and Bonas 1996). The upstream sequence of the $H r c C$ open reading frame (ORF) (hrpA operon) of $X$. campestris pv. campestris differs from that of $X$. campestris pv. vesicatoria (Fig. 3), suggesting that it may not be recognized by HrpG. Whether HrpX activates directly the $X$. campestris pv. campestris hrpA is not clear, because no typical or imperfect PIP box motif (Cunnac et al. 2004; Koebnik et al. 2006) is present in the $h r p A$ promoter region (Fig. 3). A number of genes without a PIP box, including $h r p E$ operon, have been described as being expressed in an HrpX-dependent manner and possible indirectly regulatory models have been proposed (Koebnik et al. 2006).

Interestingly, a BlastN result showed that the sequences of the IGR between $h r p B 8$ and $h r c C$ (the upstream sequence of hrpA ORF) in Xanthomonas spp. fall into two groups: group 1 is a long IGR (181 bp), which is present in all of the sequenced X. campestris pv. campestris 8004, ATCC33913, and B100 (almost identical among the three strains); and group 2 is a short IGR $(81 \mathrm{bp})$, which exists in all of the sequenced strains of $X$. campestris pv. vesicatoria, $X$. axonopodis pv. citri, $X$. fuscans subsp. fuscans, $X$. axonopodis pv. glycines, and $X$. oryzae pv. oryzae (approximately $90 \%$ identity among these strains). Recently, Seo and associates (2008) found that, except for hrpal and hrpE, other hrp genes of X. oryzae pv. oryzicola are not induced in the minimal medium XOM2, a condition in which most of the hrp genes of X. oryzae pv. oryzae are induced. Therefore, they concluded that the regulation of the hrp genes between $X$. oryzae pv. oryzae and $X$. oryzae pv. oryzicola is different (Seo et al. 2008). To further investigate the regulatory relationship among $h r p A, h r p G$, and $h r p X$ of the above xanthomonads will help us to fully understand the hrp regulatory mechanisms.

In Xanthomonas spp., the hrpA to hrpD operons contain nine $h r c$ ( $h r p$-conserved) genes that encode proteins that presumably constitute the core components of the T3SS apparatus in the inner and outer membrane of bacterial cells, and $h r p E$ and $h r p F$ encode pilin and translocon proteins, respectively, which are also important for T3SS (Büttner et al. 2003; Gürlebeck et al. 2006). The significant reduction in expression of these genes in the zur mutant may affect the T3SS assembly, resulting in a delayed and weakened HR.

Because a mutation in $h r p G$ does not affect zinc homeostasis of $X$. campestris pv. campestris (data not shown), it is logical to assume that the expression of zur is not under the control of HrpG. A putative transcriptional regulatory gene, named $t r h$, has been demonstrated to be involved in the expression of hrp $G$ of $X$. oryzae pv. oryzae, although whether the regulation is direct or indirect is unknown (Tsuge et al. 2006). Recently, we have identified several additional regulatory genes, $h p a R$, $r s m A_{X c c}, c o l R_{X C 1049}$, and col $S_{X C 1050}$, which are involved in HR and pathogenicity of $X$. campestris pv. campestris (Chao et al. 2008; Wei et al. 2007; Zhang et al. 2008). hpaR is a marR family transcriptional regulator and its expression is positively controlled by HrpG and HrpX, and it does not regulate the expression of $h r p A$ to $h r p F$ operons (Wei et al. 2007). RsmA $A_{\mathrm{Xcc}}$ is a putative RNA-binding protein involved in the control of various cellular processes and positively regulates the expression of $h r p A$ to $h r p F$ operons but not $h r p G$ and $h r p X$ (Chao et al. 2008). $\operatorname{col} R_{X C 1049}$ and $\operatorname{col} S_{X C 1050}$ encode a putative two-component signal transduction system implicated in virulence, HR, and tolerance to various stresses, and positively regulates the expression of $h r p C$ and $h r p E$ operons but not other $h r p$ genes; and the expression of $\operatorname{col}_{X C 1049}$ and $\operatorname{col} S_{X C 1050}$ is not controlled by HrpG and HrpX (Zhang et al. 2008). To the best of our knowledge, concerning hrp regulation only, the $X$. campestris pv. campestris Zur represents a novel key regulator that acts upstream of the key regulator $\operatorname{HrpX}$ but is not regulated by HrpG (Fig. 5).

This work has also shown that the effects of Zur on HR induction, EPS production, and zinc homeostasis are probably through different regulatory pathways in $X$. campestris pv. campestris. Promoter-gusA reporter analysis revealed that the $X$. campestris pv. campestris Zur may not regulate the expression of the EPS production-associated genes $c l p, g u m B$, ops $X$, and $r p f C$ (Tang et al. 2005). Recently, we have demonstrated that Zur functions as a repressor and an activator of putative zinc homeostasis genes via recognizing two distinct sequences within its target promoters in $X$. campestris pv. campestris (Huang et al. 2008). Bacterial Zur is a member of the Fur family of transcriptional regulators. Ellermeier and Slauch (2008) have demonstrated that the Fur of the animal pathogen Salmonella enterica serovar typhimurium regulates expression of the Salmonella pathogenicity island 1 (SPI1) T3SS through the AraC-like transcriptional activator HilD, a key regulator of Salmonella T3SS, which can activate hilA that encodes the direct regulator of the SPI1 structural genes. They have also shown that the Fur does not directly regulate the transcription of hilD, although the mechanism by which the Fur regulates hilD is still unclear (Ellermeier and Slauch 2008). To further investigate the mechanism by which Zur controls the expression of $h r p X$ and the production of EPS will facilitate our understanding of the regulatory mechanisms of the Fur regulator family.

\section{MATERIALS AND METHODS}

Bacterial strains, plasmids, and growth conditions.

The bacterial strains and plasmids used in this work are listed in Table 1. E. coli strains were grown in L medium (Miller 1972) at $37^{\circ} \mathrm{C}$. X. campestris pv. campestris strains were grown in NYG medium (Daniels et al. 1984a) or MMX medium (Daniels et al. 1984b) at $28^{\circ} \mathrm{C}$. Antibiotics were used at the following final concentrations: ampicillin, $100 \mu \mathrm{g} / \mathrm{ml}$; chloramphenicol, $100 \mu \mathrm{g} / \mathrm{ml}$; kanamycin, $25 \mu \mathrm{g} / \mathrm{ml}$; rifampicin, $50 \mu \mathrm{g} / \mathrm{ml}$; and tetracycline, $15 \mu \mathrm{g} / \mathrm{ml}$ for $E$. coli and 5 $\mu \mathrm{g} / \mathrm{ml}$ for $X$. campestris pv. campestris.

\section{DNA manipulation.}

DNA manipulation was performed following the procedures described by Sambrook and associates (1989). The conjugation between the $X$. campestris pv. campestris and E. coli strains was performed as described by Turner and associates (1985). Restriction enzymes and DNA ligase were used in accordance with the manufacturer's instructions (Promega, Shanghai, China).

\section{Construction of pR3X and pR3G.}

To construct $h r p X$ and $h r p G$ constitutive expression plasmids, 1,523- and 899-bp DNA fragments, including promoterless $h r p X$ and $h r p G$ genes, respectively, with RBS were amplified by PCR using the total DNA of the wild-type strain 8004 as template and the primer sets hrpXPF/hrpXPR and hrpGPF/hrpGPR. After purification using the QIAquick PCR purification kit (Qiagen, Hilden, Germany), the two fragments were confirmed by sequencing and cloned into the broad-host- 
range vector pLAFR3 under the control of lac promoter to generate the recombinant plasmids $\mathrm{pR} 3 \mathrm{X}$ and $\mathrm{pR} 3 \mathrm{G}$ (Table 1).

\section{Semiquantitative RT-PCR analysis.}

To carry out semiquantitative RT-PCR analysis, RNA was isolated from cultures of the $X$. campestris pv. campestris strains grown to an optical density at $600 \mathrm{~nm}\left(\mathrm{OD}_{600}\right)$ of 1.0 in the minimal medium MMX. The same amount of RNA from different strains was used to convert to cDNA using a TaKaRa RNA PCR Kit (AMV; ver. 3.0; TaKaRa Biotechnology Co., Led. Dalian, China). The cDNAs were used as templates for PCR amplification with Taq polymerase. PCR was performed with a cycler using the following cycle parameters: 30 cycles of $94^{\circ} \mathrm{C}$ for $15 \mathrm{~s}, 60 \mathrm{vC}$ for $15 \mathrm{~s}$, and $72^{\circ} \mathrm{C}$ for $15 \mathrm{~s}$. The amplified products were analyzed in $1.2 \%$ agarose gels. The $16 \mathrm{~S}$ rRNA gene of $X$. campestris pv. campestris was used as the internal control to verify the absence of significant variation at cDNA level in the samples.

\section{GUS activity assay.}

$X$. campestris. pv. campestris strains were cultured in the minimal medium MMX for $48 \mathrm{~h}$. GUS activities were determined by measurement of the $\mathrm{OD}_{415}$, using $\rho$-nitrophenyl $\beta$-Dglucuronide as substrate, as described by Jefferson and associates (1986).

\section{Measurement of EPS production.}

The EPS production was measured as described by Wilson and associates (1998) with a minor modification. Overnight culture $\left(\mathrm{OD}_{600}\right.$ of approximately 1.0$)$ of each $X$. campestris pv. campestris strain $(2 \mathrm{ml})$ was used to inoculate $100 \mathrm{ml}$ of $\mathrm{NYG}$ medium containing $4 \%$ glucose in a 500-ml flask and kept at $28^{\circ} \mathrm{C}$ with shaking at $200 \mathrm{rpm}$ for 4 days. The EPS was precipitated from the culture supernatant by addition of 3 volumes of $95 \%$ ethanol. The pelleted EPS was washed with $70 \%$ ethanol, air dried, and weighed. Three flasks were inoculated in each experiment and each experiment was repeated three times.

\section{Determination of $\mathbf{H R}$.}

The HR was tested on pepper cv. ECW-10R (C. annuum cv. ECW-10R), which is one of the nonhosts commonly used to test the HR of $X$. campestris pv. campestris (Castañeda et al. 2005; Newman et al. 2001). The plants were inoculated by infiltrating approximately $5 \mu \mathrm{l}$ of bacterial suspension $\left(1 \times 10^{8}\right.$ $\mathrm{CFU} / \mathrm{ml})$ in $10 \mathrm{mM}$ sodium phosphate buffer $(5.8 \mathrm{mM}$ $\mathrm{Na}_{2} \mathrm{HPO}_{4}$ and $4.2 \mathrm{mM} \mathrm{NaH} \mathrm{PO}_{4}, \mathrm{pH} 7.0$ ) into the pepper leaves by a blunt-end plastic syringe. The inoculated plants were maintained in a greenhouse with a 12-h day and night cycle, illumination by fluorescent lamps, and a constant temperature of $28^{\circ} \mathrm{C}$ and were observed at $8,16,24,36$, and $48 \mathrm{~h}$ after inoculation. At least three plants were inoculated in each experiment and each experiment was repeated at least twice.

\section{Virulence assay.}

The virulence of the $X$. campestris pv. campestris strains was tested on potted Chinese radish ( $R$. sativus L. var. radiculus Pers.) grown in a greenhouse with a 12-h day and night cycle and illumination by fluorescent lamps at 25 to $28^{\circ} \mathrm{C}$. Seedlings with four fully expanded leaves were used for inoculation. Bacterial cells were grown in NYG medium at $28^{\circ} \mathrm{C}$ with shaking at $200 \mathrm{rpm}$ for $15 \mathrm{~h}$ (at the exponential phase of growth). The concentration of bacterial inocula was adjusted to $\mathrm{OD}_{600}$ of 0.1 . Two leaves per plant were inoculated by the leafclipping method (Dow et al. 2003). Sixty leaves were inoculated for each independent experiment. After maintenance in $100 \%$ humidity for $24 \mathrm{~h}$, the inoculated plants were main- tained in the growth conditions described above. Lesion length was measured 10 days post inoculation. The same experiment was repeated three times.

\section{EMSA.}

EMSA was performed following the procedure described by Gaballa and Helmann (1998). DNA fragments containing the promoter regions of $X C 3788\left(\mathrm{P}_{3788}\right)$ or $h r p X\left(\mathrm{P}_{h r p X}\right)$ were amplified by PCR using the total DNA of the wild-type strain 8004 as template and the primer sets $\mathrm{P}_{3788}-\mathrm{F} / \mathrm{P}_{3788}-\mathrm{R}$ and $\mathrm{P}_{\text {hrp }}{ }^{-}$ $\mathrm{F} / \mathrm{P}_{\mathrm{hrpX}}-\mathrm{R}$. After purification using the QIAquick PCR purification kit (Qiagen), the obtained PCR products were labeled with $\left[\gamma-{ }^{32} \mathrm{P}\right]$ ATP using a $5^{\prime}$ end-labeled kit (TaKaRa). Then, the His $_{6}$-Zur protein (Huang et al. 2008) was added into a $1.5-\mathrm{ml}$ EP tube containing $20 \mu \mathrm{l}$ of binding buffer $(20 \mathrm{mM}$ Tris- $\mathrm{HCl}$ [pH 8], $50 \mathrm{mM} \mathrm{KCl}, 1 \mathrm{mM}$ dithiothreitol, $5 \%$ glycerol, bovine serum albumin at $0.1 \mathrm{mg} / \mathrm{ml}$, and sheared salmon sperm DNA at $5 \mu \mathrm{g} / \mathrm{ml}$ ) to final concentrations of $0,32,320$, and $3200 \mathrm{nM}$, and 3 pmol of labeled DNA was added to each tube and mixed well. The mixtures were incubated at room temperature for 20 min. Samples were then loaded on a $4 \%$ polyacrylamide gel prepared and run in $40 \mathrm{mM}$ Tris-acetate buffer (with no EDTA) (pH 8.0). The gel was dried and exposed to a phosphorimager screen (Typhoon 9410; Amersham Biosciences, Piscataway, NJ, U.S.A.).

\section{ACKNOWLEDGMENTS}

This work was supported by the National Natural Science Foundation of China (30671142 and 30730004) and the '863' Program of the Ministry of Science and Technology of China (2006AA02Z175).

\section{LITERATURE CITED}

Alfano, J. R., and Collmer, A. 1997. The type III (Hrp) secretion pathway of plant pathogenic bacteria: Trafficking harpins, Avr proteins, and death. J. Bacteriol. 179:5655-5662.

Alfano, J. R., and Collmer, A. 2004. Type III secretion system effector proteins: Double agents in bacterial disease and plant defense. Annu. Rev. Phytopathol. 42:385-414.

Arlat, M., Gough, C. L., Barber, C. E., Boucher, C., and Daniels, M. J. 1991. Xanthomonas campestris contains a cluster of hrp genes related to the larger hrp cluster of Pseudomonas solanacearum. Mol. PlantMicrobe Interact. 4:593-601.

Bonas, U., Schulte, R., Fenselau, S., Minsavage, G. V., Staskawicz, B. J., and Stall, R. E. 1991. Isolation of a gene cluster from Xanthomonas campestris pv. vesicatoria that determines pathogenicity and the hypersensitive response on pepper and tomato. Mol. Plant-Microbe Interact. 4:81-88.

Büttner, D., and Bonas, U. 2006. Who comes first? How plant pathogenic bacteria orchestrate type III secretion. Curr. Opin. Microbiol. 9:193200.

Büttner, D., Noel, L., Thieme, F., and Bonas, U. 2003. Genomic approaches in Xanthomonas campestris pv. vesicatoria allow fishing for virulence genes. J. Biotechnol. 106:203-214.

Castañeda, A., Reddy, J. D., El-Yacoubi, B., and Gabriel, D. W. 2005. Mutagenesis of all eight avr genes in Xanthomonas campestris pv. campestris had no detected effect on pathogenicity, but one avr gene affected race specificity. Mol. Plant-Microbe Interact. 18:1306-1317.

Chan, J. W., and Goodwin, P. H. 1999. The molecular genetics of virulence of Xanthomonas campestris. Biotechnol. Adv. 17:489-508.

Chao, N. X., Wei, K., Chen, Q., Meng, Q. L., Tang, D. J., He, Y.Q., Lu, G. T., Jiang, B. L., Liang, X. X., Feng, J. X., Chen, B., and Tang, J. L. 2008. The rsmA-like gene $r s m A_{X c c}$ of Xanthomonas campestris pv. campestris is involved in the control of various cellular processes, including pathogenesis. Mol. Plant-Microbe Interact. 21:411-423.

Cornelis, G. R., and Van Gijsegem, F. 2000. Assembly and function of type III secretory systems. Annu. Rev. Microbiol. 54:735-774.

Cunnac, S., Boucher, C., and Genin, S. 2004. Characterization of the cisacting regulatory element controlling HrpB-mediated activation of the type III secretion system and effector genes in Ralstonia solanacearum. J. Bacteriol. 186:2309-2318.

Daniels, M. J., Barber, C. E., Turner, P. C., Sawczyc, M. K., Byrde, R. J. 
W., and Fielding, A. H. 1984a. Cloning of genes involved in pathogenicity of Xanthomonas campestris pv. campestris using the broadhost-range cosmid pLAFR1. EMBO (Eur. Mol. Biol. Organ.) J. 3:33233328 .

Daniels, M. J., Barber, C. E., Turner, P. C., Cleary, W. G., and Sawczyc, M. K. 1984b. Isolation of mutants of Xanthomonas campestris pathovar campestris showing altered pathogenicity. J. Gen. Microbiol. 130:24472455

Dow, J. M., Crossman, L., Findlay, K., He, Y. Q., Feng, J. X., and Tang, J. L. 2003. Biofilm dispersal in Xanthomonas campestris is controlled by cell-cell signaling and is required for full virulence to plants. Proc. Natl. Acad. Sci. U.S.A. 100:10995-11000.

Ellermeier, J. R., and Slauch, J. M. 2008. Fur regulates expression of the Salmonella pathogenicity island 1 type III secretion system through HilD. J. Bacteriol. 190:476-486.

Gaballa, A., and Helmann, J. D. 1998. Identification of a zinc-specific metalloregulatory protein, Zur, controlling zinc transport operons in Bacillus subtilis. J. Bacteriol. 180:5815-5821.

Gürlebeck, D., Thieme, F., and Bonas, U. 2006. Type III effector proteins from the plant pathogen Xanthomonas and their role in the interaction with the host plant. J. Plant Physiol. 163:233-255.

Hantke, K. 2001. Bacterial zinc transporters and regulators. Biometals $14: 239-249$.

Hantke, K. 2005. Bacterial zinc uptake and regulators. Curr. Opin. Microbiol. 8:196-202.

Hayward, A. C. 1993. The host of Xanthomonas. Pages 51-54 in: Xanthomonas. J. G. Swings and E. L. Civerolo, eds. Chapman \& Hall, London.

He, S. Y. 1998. Type III protein secretion systems in plant and animal pathogenic bacteria. Annu. Rev. Phytopathol. 36:363-392.

He, Y. W., Ng, A., Xu, M., Lin, K., Wang, L. H., Dong, Y. H., and Zhang, L. H. 2007a. Xanthomonas campestris cell-cell communication involves a putative nucleotide receptor protein Clp and a hierarchical signalling network. Mol. Microbiol. 64:281-292.

He, Y. Q., Zhang, L., Jiang, B. L., Zhang, Z. C., Xu, R. Q., Tang, D. J., Qin, J., Jiang, W., Zhang, X., Liao, J., Cao, J. R., Zhang, S. S., Wei, M. L., Liang, X. X., Lu, G. T., Feng, J. X., Chen, B. S., Cheng, J., and Tang, J. L. 2007b. Comparative and functional genomics reveals genetic diversity and determinants of host specificity among reference strains and a large collection of Chinese isolates of the phytopathogen Xanthomonas campestris pv. campestris. Genome Biol. 8(10):R218.

Huang, D. L., Tang, D. J., Liao, Q., Li, H. C., Chen, Q., He, Y. Q., Feng, J. X., Jiang, B. L., Lu, G., T., Chen, B., and Tang, J. L. 2008. The Zur of Xanthomonas campestris functions as a repressor and an activator of putative zinc homeostasis genes via recognizing two distinct sequences within its target promoters. Nucleic Acids Res. 36:4295-4309.

Hueck, C. J. 1998. Type III protein secretion systems in bacterial pathogens of animals and plants. Microbiol. Mol. Biol. Rev. 62:379-433.

Huynh, T. V., Dahlbeck, D., and Staskawicz, B. J. 1989. Bacterial blight of soybean: Regulation of a pathogen gene determining host cultivar specificity. Science 245:1374-1377.

Jefferson, R. A., Burges, S. M., and Hirsh, D. 1986. ß-glucuronidase from Escherichia coli as a gene-fusion marker. Proc. Natl. Acad. Sci. U.S.A. 83:8447-8451.

Jones, J. D. G., and Dangl, J. L. 2006. The plant immune system. Nature 444:323-329.

Koebnik, R., Krüger, A., Thieme, F., Urban, A., and Bonas, U. 2006. Specific binding of the Xanthomonas campestris pv. vesicatoria AraC-type transcriptional activator $\mathrm{HrpX}$ to plant-inducible promoter boxes. J. Bacteriol. 188:7652-7660.

Leong, S. A., Ditta, G. S., and Helinski, D. R. 1982. Heme biosynthesis in Rhizobium. Identification of a cloned gene coding for delta-aminolevulinic acid synthetase from Rhizobium meliloti. J. Biol. Chem. 257:87248730 .

Lindgren, P. B. 1997. The role of hrp genes during plant-bacterial interactions. Annu. Rev. Phytopathol. 35:129-152.

Miller, J. H. 1972 Experiments in Molecular Genetics. Cold Spring Harbor Laboratory Press, Cold Spring Harbor, NY, U.S.A.

Newman, M. A., von Roepenack-Lahaye, E., Parr, A., Daniels, M. J., and Dow, J. M. 2001. Induction of hydroxycinnamoyl-tyramine conjugates in pepper by Xanthomonas campestris, a plant defense response activated by hrp gene-dependent and hrp gene-independent mechanisms. Mol. Plant-Microbe Interact. 14:785-792.

Outten, C. E., and O'Halloran, T. V. 2001. Femtomolar sensitivity of metalloregulatory proteins controlling zinc homeostasis. Science 292:2488-2492.

Patzer, S. I., and Hantke, K. 2000. The zinc-responsive regulator Zur and its control of the znu gene cluster encoding the ZnuABC zinc uptake system in Escherichia coli. J. Biol. Chem. 275:24321-24332.
Qian, W., Jia, Y., Ren, S. X., He, Y. Q., Feng, J. X., Lu, L. F., Sun, Q., Ying, G., Tang, D. J., Tang, H., Wu, W., Hao, P., Wang, L., Jiang, B. L., Zeng, S., Gu, W. Y., Lu, G., Rong, L., Tian, Y., Yao, Z., Fu, G., Chen, B., Fang, R., Qiang, B., Chen, Z., Zhao, G. P., Tang, J. L., and $\mathrm{He}, \mathrm{C} .2005$. Comparative and functional genomic analyses of the pathogenicity of phytopathogen Xanthomonas campestris pv. campestris. Genome Res. 15:757-767.

Sambrook, J., Fritsch, E. F., and Maniatis, T. 1989. Molecular Cloning: A Laboratory Manual, 2nd ed. Cold Spring Harbor Laboratory, Cold Spring Harbor, NY, U.S.A.

Seo, Y. S., Sriariyanun, M., Wang, L., Pfeiff, J., Phetsom, J., Lin, Y., Jung, K. H., Chou, H. H., Bogdanove, A., and Ronald, P. 2008. A twogenome microarray for the rice pathogens Xanthomonas oryzae pv. oryzae and $X$. oryzae pv. oryzicola and its use in the discovery of a difference in their regulation of hrp genes. BMC Microbiol. 8:99.

Tang, D. J., Li, X. J., He, Y. Q., Feng, J. X., Chen, B., and Tang, J. L. 2005. The zinc uptake regulator Zur is essential for the full virulence of Xanthomonas campestris pv. campestris. Mol. Plant-Microbe Interact. 18:652-658.

Tang, J. L., Liu, Y. N., Barber, C. E., Dow, J. M., Wootton, J. C., and Daniels, M. J. 1991. Genetic and molecular analysis of a cluster of $r p f$ genes involved in positive regulation of synthesis of extracellular enzymes and polysaccharide in Xanthomonas campestris pathovar campestris. Mol. Gen. Genet. 226:409-417.

Tang, X., Xiao, Y., and Zhou, J. M. 2006. Regulation of the type III secretion system in phytopathogenic bacteria. Mol. Plant-Microbe Interact. 19:1159-1166.

Tsuge, S., Nakayama, T., Terashima, S., Ochiai, H., Furutani, A., Oku, T., Tsuno, K., Kubo, Y., and Kaku, H. 2006. Gene involved in transcriptional activation of the $h r p$ regulatory gene $h r p G$ in Xanthomonas oryzae pv. oryzae. J. Bacteriol. 188:4158-4162.

Turner, P., Barber, C. E, and Daniels, M. J. 1985. Evidence for clustered pathogenicity genes in Xanthomonas campestris pv. campestris. Mol. Gen. Genet. 199:338-343.

Weber E., Berger, C., Bonas, U., and Koebnik, R. 2007. Refinement of the Xanthomonas campestris pv. vesicatoria hrpD and hrpE operon structure. Mol. Plant-Microbe Interact. 20:559-567.

Wei, K., Tang, D. J., He, Y.Q., Feng, J. X., Jiang, B. L., Lu, G. T., Chen, B., and Tang, J. L. 2007. hpaR, a putative marR family transcriptional regulator, is positively controlled by $\mathrm{HrpG}$ and $\mathrm{HrpX}$ and involved in the pathogenesis, hypersensitive response, and extracellular protease production of Xanthomonas campestris pathovar campestris. J. Bacteriol. 189:2055-2062.

Wengelnik, K., and Bonas, U. 1996. HrpXv, an AraC-type regulator, activates expression of five of six loci in the hrp cluster of Xanthomonas campestris pv. vesicatoria essential for pathogenicity and induction of the hypersensitive reaction. J. Bacteriol. 178:3462-3469.

Wengelnik, K., Marie, C., Russel, M., and Bonas, U. 1996a. Expression and localization of HrpA1, a protein of Xanthomonas campestris pv. vesicatoria essential for pathogenicity and induction of the hypersensitive reaction. J. Bacteriol. 178:1061-1069.

Wengelnik, K., Van den Ackerveken, G., and Bonas, U. 1996b. HrpG, a key hrp regulatory protein of Xanthomonas campestris pv. vesicatoria, is homologous to two-component response regulators. Mol. Plant-Microbe Interact. 9:704-712.

Wilson, T. J., Bertrand, N., Tang, J-L., Feng, J-X., Pan, M-Q., Barber, C. E., Dow, J. M., and Daniels, M. J. 1998. The rpfA gene of Xanthomonas campestris pathovar campestris, which is involved in the regulation of pathogenicity factor production, encodes an aconitase. Mol. Microbiol. 28:961-970.

Yang, W., Liu, Y., Chen, L., Gao, T., Hu, B., Zhang, D., and Liu, F. 2007. Zinc uptake regulator (zur) gene involved in zinc homeostasis and virulence of Xanthomonas oryzae pv. oryzae in rice. Curr. Microbiol. 54:307-314.

Yanisch-Perron, C., Vieira, J., and Messing, J. 1985. Improved M13 phage cloning vectors and host strains: Nucleotide sequences of the M13mp18 and pUC19 vectors. Gene 33:103-119.

Zhang, S. S., He, Y. Q., Xu, L. M., Chen, B. W., Jiang, B. L., Liao, J., Cao, J. R., Liu, D., Huang, Y. Q., Liang, X. X., Tang, D. J., Lu, G. T., and Tang, J. L. 2008. A putative $\operatorname{col} R_{X C 1049}-\operatorname{col} S_{X C 1050}$ two-component signal transduction system in Xanthomonas campestris positively regulates $h r p C$ and $h r p E$ operons and is involved in virulence, the hypersensitive response, and tolerance to various stresses. Res. Microbiol. 159:569-578.

\section{AUTHOR-RECOMMENDED INTERNET RESOURCE}

National Center for Biotechnology Information website: www.ncbi.nlm.nih.gov/ 